\title{
The Effects of Cracks on the Modulus of Rupture of Concrete
}

\author{
Zarak Khan Kasi, Saeedullah Jan Mandokhail, Nawaz Ali Kakar, Marjan Gul Kakar, Meer Hamza Khan \\ Jogezai
}

Department of Civil Engineering, Faculty of Engineering and Architecture, Balochistan University of Information Technology, Engineering and Management Sciences, Quetta, Pakistan

\begin{abstract}
The purpose of this study was to experimentally investigate the effects of cracking on the modulus of rupture (MOR) of concrete. When a structural member (e.g. column member) is subjected to dynamic loading, the tensile and compressive parts are interconverted on each stress reversal. The cracks may initiate in the tensile part due to the cyclic loading depending on the magnitude of stresses. Such understanding is critical in understanding the overall effects of cyclic loading on the building and on the strength of concrete.

In this paper, the effect of such cracks on MOR were studied by conducting detailed laboratory tests. Reinforced beams were prepared by using three different concrete mix designs. The center point load flexural tests on beams were conducted by producing initial cracks in the tension zone and then switching the cracked tensile zone into compressive zone to study the effects of cracks on the MOR. The MOR of cracked and uncracked beams were compared. The experimental results shown that the cracks had no pronounced effect on MOR.
\end{abstract}

Keywords: Cracks; Modulus of Rupture; Reversal Zone; Compressive Strength

Corresponding author's email: saeed.ullah@buitms.edu.pk

\section{INTRODUCTION}

Cracks in buildings have been long since reducing the strength of concrete and causing problems for safe and efficient environment. Earthquakes, due to their nature, effect buildings and initiate cracks, which if not considered properly may cause problems in the long term. On May 16th, 2016, it was concluded that thousands of buildings were dangerous to live in due to the cracks which were resulted from the three weeks earlier Earthquake in Katmandu, Nepal. "This earthquake has reminded us that there are a lot of dangerous buildings that need to be demolished," said Bipin Gaire, a civil engineer and who have been assessing the structural integrity of the buildings. Keeping in view this statement and the overall scope of the cracks which have been caused by earthquake, a study regarding the overall effect of cracks on the strength of concrete should be studied effectively so that evidence regarding buildings safety and maintenance is measured and then an overview is provided or established for such circumstances.

Modulus of rupture (MOR) can be defined only for brittle materials where resistance to deformation is studied. In this case the proportional limit of the material is exceeded and the stress obtained is called as the modulus of rupture (Pytel and Singer, 1978). Modulus of Rupture is also known as flexural strength, bending strength and fractural strength. Modulus of rupture of concrete, which characterizes the bending strength of unreinforced beams, is known to depend on the beam size (Novak et al., 2002).

The modulus of rupture can be calculated by conducting either one of the three types of tests that are Centre-Point Loading Test ASTM C293 (ASTM, 2002b), Third-Point Loading Test ASTM C78 (ASTM, 2002a), and Compressive Test ASTM C39 (ASTM, 2005), as shown in Figure 1. The modulus of rupture of center point loading test is approximately greater than $15 \%$ of the modulus of rupture calculated in third point loading test (ACPA, 2001).

Many studies have been conducted over the past century on modulus of rupture. Novak et al., (2002) studied the experimental - analytical prediction of flexural strength by using the subway tunnel constructed in Prague as real case study for the phenomenon and provided a size-effect formula for the calculation of Modulus of Rupture. Other studies have shown the correlation between the compressive strength of concrete $\left(f_{c}^{\prime}\right)$ and the Modulus of rupture of concrete $\left(f_{r}\right)$. Issa et al., (2014) studied and compared $f_{c}^{\prime}$ and $f_{r}$ in construction joints and found that there is a reduction of $55 \%$ in the overall flexural strength when 
compared to a monolithic section. However, up to the author's knowledge no research has been carried out to study the effect of cracks, which are resulted from cyclic loading, on the Modulus of Rupture of concrete. When the column is subjected to cyclic loading, on stress reversal the tensile part is converted to compressive part and vice versa. The cracks may be initiated due to these cyclic loading. In this paper, the effect of such cracks on the modulus of rupture is investigated by conducting detailed lab tests.

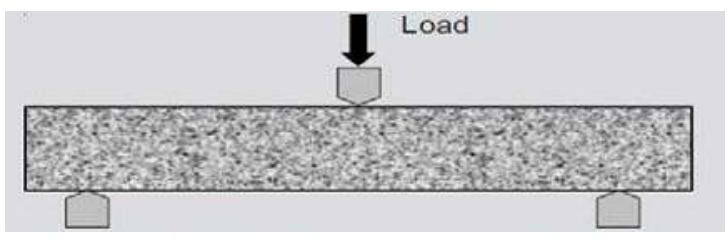

(a)

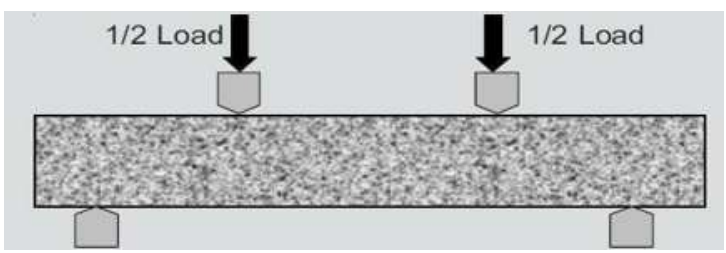

(b)

Figure 1: Test performed for Modulus of Rupture (a) Centre-Point Loading Test (b) Third-Point Loading Test (ASTM,

\section{MATERIALS AND METHODS} $2002 a, b)$

For this research study, concrete cylinders rand reinforced beams samples were prepared. The contents of concrete were mixed by using volumetric method (ASTM, 2012). Volumetric method was used so that the samples are more representative of the practical applications of site. Cement, sand and aggregate were mixed in the ratio $1: 1: 2,1: 1.5: 3$ and 1:2:4. All the samples were cured for 28 days at room temperature and then taken for testing. The Aggregate size was taken in accordance to ASTM C33 (ASTM, 2003) (which should be passing through the sieves $3 / 4$ "to 4 "). The water to cement ratio was taken as 0.5 . Each ratio had 2 cylindrical samples of 6" diameter and 12" height and 18 beam samples of 21 " length and 6" width and height.

Nine beams samples were prepared with initial cracks and nine beams samples were prepared with no initial cracks. The beam samples were casted for the modulus of rupture testing, whereas the cylinder samples were casted for the compressive strength of concrete. The beam samples were reinforced in accordance to the $\mathrm{ACl}$ balanced reinforcement $(\mathrm{ACl}, 2008)$.

$$
\rho_{b}=\frac{0.85 f_{c}^{\prime} \beta}{f_{y}}\left(\frac{87,000}{f_{y}+87,000}\right)
$$

where $\rho_{b}=$ balanced reinforcement ratio, $\quad f_{c}^{\prime}=$ compressive strength of concrete at 28 days, $\beta=$ coefficient of compression, $f_{y}=$ yielding strength of steel. It was considered that the sample reinforcement was less than the calculated $\rho_{b}$ value intended to achieve under reinforcement. The reinforcement was provided equally on both sides of the beam.

\section{Testing}

Compressive test in accordance with the ASTM standard (ASTM, 2005) were conducted on 6 cylindrical samples. The aim of these tests were to determine $f_{c}^{\prime}$ and to calculate balanced reinforcement ratio as in Equation (1). The 18 beam samples were tested for flexure strength by conducting Centre-Point Loading Test according to ASTM standard (ASTM, 2002b). Nine of the eighteen beams were tested un-cracked, 
while the other nine were tested by first generating hair line cracks on one side (tensile zone) by applying some amount of load at the center of the beam. After the cracks were generated, the load was removed, and the beam was flipped such that the tensile zone (cracked zone) was now compressive zone. Centerpoint loading test was then carried out. All the tests were conducted with universal testing machine (UTM).

\section{RESULTS AND DISCUSSION}

Table 1 presents the compressive strength of cylindrical samples calculated from compression test. Results show that compressive strength for mix ratio of 1:1:2 is maximum and 1:2:4 is minimum. The flexural test results for both type of beams (with crack and without crack) are shown in Table 2. The crack width and crack length was calculated via photogrammetry and shown in Table 2. Modulus of rupture of beams with cracks and without cracks was calculated and compared. The comparison show that the modulus of rupture of beams with cracks is slightly larger than the beams without cracks, as shown in Figure 2 and Table 2. However, the MOR decreases with increase in the mix ratio for both cracked and uncracked cases. The concrete stress-strain relationships of cracked and uncracked samples were determined directly from the results of flexural tests on reinforced concrete beams and compared, as shown in Figure 3. The comparison demonstrate that the cracks has no pronounced effect on the stress-strain behavior. The reason behind the cracked beam showing similar behavior to that of uncracked beams can be due the tensile residual stresses induced during the formation of cracks.

Table 1: Compressive tests results of cylinder

\begin{tabular}{|c|c|c|c|c|}
\hline S.No. & Sample ID & $\begin{array}{l}\text { Concrete } \\
\text { Mix Ratio }\end{array}$ & $\begin{array}{l}\text { Compressive } \\
\text { Strength (psi) }\end{array}$ & $\begin{array}{l}\text { Compressive } \\
\text { Strength (psi) }\end{array}$ \\
\hline 1 & 112.1 & \multirow{2}{*}{$1: 1: 2$} & 2882 & \multirow[b]{2}{*}{2903} \\
\hline 2 & 112.2 & & 2924 & \\
\hline 3 & 11.53. 1 & \multirow{2}{*}{$1: 1.5: 3$} & 2181 & \multirow{2}{*}{2147} \\
\hline 4 & 11.53 .2 & & 2113 & \\
\hline 5 & 124.1 & \multirow{2}{*}{$1: 2: 4$} & 1639 & \multirow{2}{*}{1661} \\
\hline 6 & 124.2 & & 1683 & \\
\hline
\end{tabular}

Table 2: Flexural tests results of beam with cracks and without cracks

\begin{tabular}{|c|c|c|c|c|c|c|c|c|}
\hline \multirow[b]{2}{*}{ S.No. } & \multirow[b]{2}{*}{$\begin{array}{l}\text { Sample } \\
\text { ID }\end{array}$} & \multirow[b]{2}{*}{$\begin{array}{l}\text { Concrete } \\
\text { Mix Ratio }\end{array}$} & \multicolumn{2}{|c|}{$\begin{array}{l}\text { Beam samples } \\
\text { with no cracks }\end{array}$} & \multicolumn{4}{|c|}{ Beam samples with cracks } \\
\hline & & & $\begin{array}{l}\text { MOR } \\
\text { (psi) }\end{array}$ & & $\begin{array}{c}\text { Crack } \\
\text { Width } \\
\text { (in) }\end{array}$ & $\begin{array}{l}\text { Crack } \\
\text { Length } \\
\text { (in) }\end{array}$ & $\begin{array}{l}\text { MOR } \\
\text { (psi) }\end{array}$ & $\begin{array}{l}\text { MOR } \\
\text { (psi) }\end{array}$ \\
\hline 1 & 112.1 & \multirow{3}{*}{$1: 1: 2$} & 1766 & \multirow{3}{*}{1966} & 0.087 & 5.36 & 1869 & \multirow{3}{*}{2009} \\
\hline 2 & 112.2 & & 2157 & & 0.060 & 4.90 & 1987 & \\
\hline 3 & 112. 3 & & 1974 & & 0.040 & 5.03 & 2171 & \\
\hline 4 & 11.53 .1 & \multirow{3}{*}{$1: 1.5: 3$} & 1680 & \multirow{3}{*}{1723} & 0.070 & 4.26 & 1732 & \multirow{3}{*}{1739} \\
\hline 5 & 11.53 .2 & & 1738 & & 0.357 & 4.57 & 1697 & \\
\hline 6 & 11.53. 3 & & 1751 & & 0.083 & 4.02 & 1787 & \\
\hline 7 & 124.1 & \multirow{3}{*}{$1: 2: 4$} & 1341 & \multirow{3}{*}{1238} & 0.047 & 4.03 & 1385 & \multirow{3}{*}{1270} \\
\hline 8 & 124.2 & & 1209 & & 0.165 & 4.25 & 1237 & \\
\hline 9 & 124.3 & & 1163 & & 0.110 & 4.26 & 1189 & \\
\hline
\end{tabular}




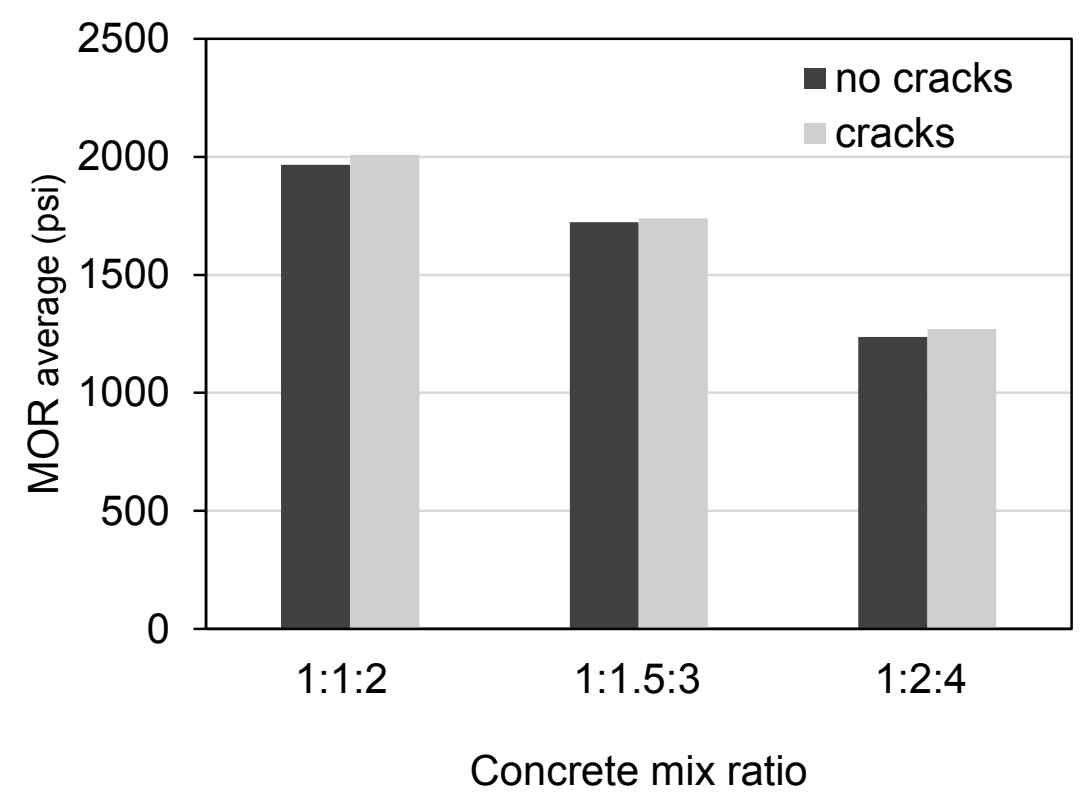

Figure 2: Comparison of flexural strength of beams with cracks and without cracks
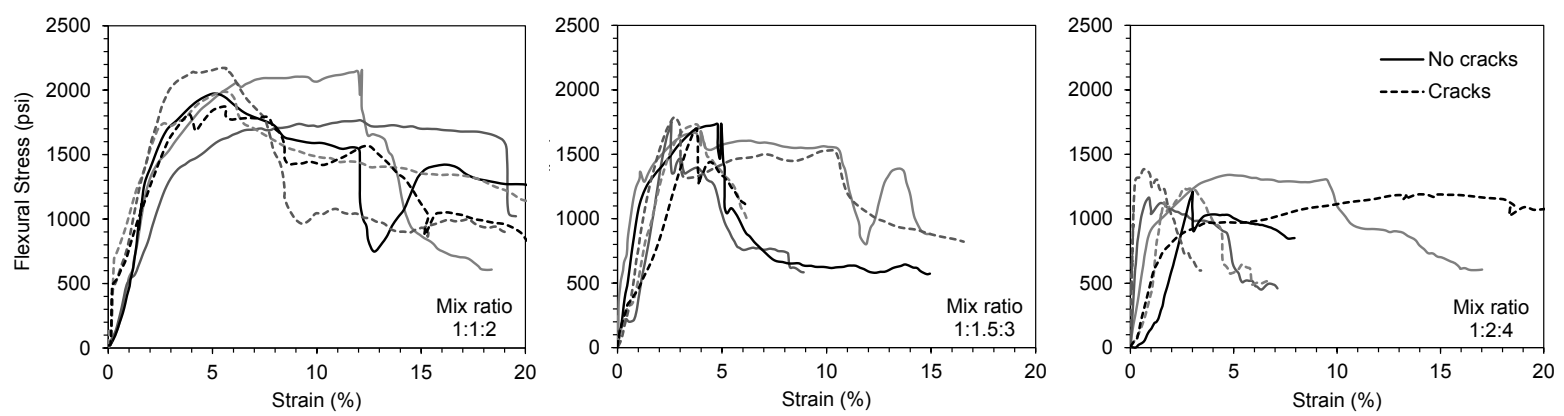

Figure 3: Comparison of stress-strain behavior of beam with cracks and without cracks

\section{CONCLUSION}

In this study the effect of cracking on the modulus of rupture of beam was studied by conducting laboratory tests. A total of 18 concrete beams measuring $21 \times 6 \times 6$ in were constructed and tested under center point bending to failure. Nine beams were tested with initially uncracked and nine were tested with initially cracked. The experimental results were compared considering cracks and the mix ratio. The comparison showed no significant effect of cracking on the modulus of rupture of concrete. The average value of the MOR was slightly increased with cracks, however, it was gradually decreased with increase in the mix ratio. The stress-strain behavior was also compared and shown that the cracks has no pronounced effect on the stress-strain behavior. This can be due to the residual stresses present in the cracked samples. 


\section{REFERENCES}

- ACl. (2008). Building code requirements for structural concrete and commentary. ACI 318.

- ASTM. (2002a). Standard test method for flexural strength of concrete. ASTM C 78, West Conshohocken, PA.

- ASTM. (2002b). Standard test method for flexural strength of concrete (Using Simple Beam With Center-Point Loading). ASTM C 239, West Conshohocken, PA.

- ASTM. (2003) Standard Specification for Concrete Aggregates. ASTM C 33, West Conshohocken, PA.

- ASTM. (2005). Standard test method for compressive strength of cylindrical concrete specimens. ASTM C 39/C 39M, West Conshohocken, PA.

- ASTM. (2012) Standard Specification for Concrete Made by Volumetric Batching and Continuous Mixing. ASTM C 685/C 685M - 01, West Conshohocken, PA.

- Issa CA, Gerges NN, Fawaz S. (2014). The effect of concrete vertical construction joints on the modulus of rupture. Case Studies in Construction Materials 1:25-32.

- Novak D, Bazant ZP, Vitek JL. (2002). Experimental-analytical size-dependent prediction of modulus of rupture of concrete. Non-traditional Cement and Concrete, ed by V Bilek and Z Kersner, ISBN:80-214.

- Pytel A, Singer FL. (1978). Strength of materials, 4th Edition. Harpercollins College Div, 4th edition. 